Pak. j. sci. ind. res. Ser. A: phys. sci. 201558 (2) 79-89

\title{
Variability in Foliar Phenolic Composition of Several Quercus Species in Northern Mexico
}

\author{
Jorge Armando Arámbula-Salazara, Norma Almaraz-Abarcab ${ }^{\text {, José Javier Corral-Rivas }}{ }^{\text {c** }}$ \\ Eli Amanda Delgado-Alvarado ${ }^{\text {, }}$, Raúl Díaz-Moreno ${ }^{\mathfrak{c}}$ and Eusebio Montiel-Antuna ${ }^{a}$ \\ ${ }^{a}$ Facultad de Ciencias Forestales, Universidad Juárez del Estado de Durango, \\ Río Papaloapan y Blvd. Durango s/n Col. Valle del Sur, Durango, Durango, Mexico, 34120 \\ ${ }^{b}$ Centro Interdisciplinario de Investigación para el Desarrollo Integral Regional, \\ Instituto Politécnico Nacional Unidad Durango (CIIDIR-IPN-Durango), Sigma No. 119, \\ Fraccionamiento 20 de Noviembre II, Durango, Mexico, 34220 \\ 'Instituto de Silvicultura e Industria de la Madera, Universidad Juárez del Estado de Durango, \\ Blvd. del Guadiana \# 501 Ciudad Universitaria, Durango, Mexico, 34160
}

(received December 30, 2013; revised June 2, 2014; accepted June 10, 2014)

\begin{abstract}
Quantitative and qualitative composition of the foliar phenolic compounds were investigated in 81 individual specimens of several white oak species (Quercus spp.). The trees were growing in twelve locations in Durango, Mexico. The phenol profiles were determined by HPLC-DAD and a Folin-Ciocateu procedure. The results revealed that: (i) the foliar phenol profiles of all species analysed were complex and formed by 6 to 30 compounds, (ii) the flavonols mostly quercetin glycoside, isorhamnetin glycoside, kaempferol glycoside and phenolic acids were the main identified compounds, (iii) there was a high intra and inter-specific variability in the foliar phenol profiles both at the quantitative and qualitative levels, and (iv) the foliar phenol profiles indicated a slight species-specific tendency for phenols to be accumulated, although this was not clearly distinguished. Significant differences $(\mathrm{P}<0.05)$ in the content and composition of the foliar flavonoids between species were observed due to the large environmental and soil conditions variability between localities.
\end{abstract}

Keywords: Quercus chihuahuensis, Quercus arizonica, Quercus grisea, Quercus undata, Quercus convallata, foliar phenol profiles

\section{Introduction}

Quercus is the most important and largest genus of the Fagaceae family (Rodríguez and Romero, 2007). Two centres of diversity of Quercus are recognised i.e. around 125 species found in Southeast Asia and about 161 species in Mexico (Valencia, 2004). Quercus species after Pinus, constitute the second most important timber yielding group in Mexico. Approximately 86 of the Mexico's species are endemic (González-Rodríguez et al., 2004), and distributed mainly in the temperate mountainous regions (Rzedowski, 2006).

Phenolic compounds are ubiquitous secondary metabolites in plants. They cover a large group of biologically active ingredients (more than 8000 compounds) ranging from simple phenol molecules to polymeric structures with molecular mass of more than 3000 daltons (Marinova et al., 2005). The foliar phenolic composition of plants is important for several reasons, e.g., for

\footnotetext{
*Author for correspondence; E-mail: jcorral@ujed.mx
}

inhibiting phytophagous insects and for attracting pollinators (Hadacek, 2002). The broad biological activity of phenolic compounds, e.g., as antioxidants (Falleh et al., 2011; Almaraz-Abarca et al., 2007; 2006) and antibacterial compounds (Bangou et al., 2011), has also led to studies of phenolic composition in many species of plants. However, the phenolic composition of a few Quercus species have been studied, mainly with the aim of determining their biological activity including $Q$. robur (Salminen et al., 2004), Q. alba (Miller et al., 1992), Q. rubra (Warren et al., 2002), Q. miyagii (Ishimaru et al., 1987), Q. dentata (Wang et al., 2010), Q. cerris L. (Romussi et al., 1988), Q. mongolica (Ishimaru et al., 1988), Q. suber and Q. pubescens (Romussi et al., 1991), Q. incana (Iftikhar et al., 2009), Q. ilex (Karioti et al., 2011), Q. acutissima (Yeon et al., 2011), Q. infectoria (Gurpreet et al., 2008), Q. petraea (Meyer et al., 2009), Q. salicina (Jung-Il et al., 2008), Q. coccifera (Karageorgou and Manetas, 2006), Q. sideroxyla, Q. eduardii, and $Q$. resinosa 
(Rivas-Arreola et al., 2010). These species represents around $4 \%$ of the 531 species that are included in this genus (Borazan and Babaç, 2003).

Flavonoids represent the most common and widely distributed group of plant-food phenolics, and their contents and compositions are associated with the antioxidant properties of different fruits and vegetables (Harborne and Williams, 2000). Flavonoid profiles have been used as significant taxonomic markers for establishing a system of classifying several plant species (Almaraz-Abarca et al., 2006; Emerenciano et al., 2001; Fiasson et al., 1997; Abdala and Seeligmann, 1995). These chemical markers were found to be rather speciesspecific (Almaraz-Abarca et al., 2006; Míka, 2005). Changes in phenolic composition caused by environmental factors influence directly the quality of the plant material for potential uses (Santos et al., 2006).

The aim of the present study was to investigate the variability in foliar phenolic composition of the following eight Quercus species that are among the most abundant species in the temperate forests of Durango, Mexico: Q. arizonica s.l., Q. chihuahuensis, Q. grisea, Q. undata, $Q$. convallata, $Q$. aff. convallata, $Q$. arizonica intro. coccolobifolia, and $Q$. arizonica aff. transmontana. Quantitatively and qualitatively intra- and inter-specific variability in phenolic compounds were studied and their taxonomical significance was verified.

\section{Materials and Methods}

Plant material. The foliar phenol composition of individual specimens of $Q$. arizonica s.l., Q. chihuahuensis, $Q$. grisea, $Q$. undata, $Q$. convallata, $Q$. aff. convallata, Q. arizonica intro. coccolobifolia, and $Q$. arizonica aff. transmontana was analysed. The phenol composition was interpreted considering prior to morphological identification of the samples. Ecogeographic and soil information were also recorded when sampling (Table 1). Foliar samples were collected from individuals growing under variable ecological conditions. Leaves from 6 to 7 adult individuals of healthy appearance were collected in all cases. A total of 81 specimens were sampled at 12 locations. Authentication of each specimen sampled was done at the CIIDIR Herbarium in Durango City, Mexico.
Phenol extraction. Each sample was analysed individually and $2 \mathrm{~g}$ of dried and grounded leaves of each sample were macerated with $40 \mathrm{~mL} 60 \%$ methanol (v/v) in darkness and at room temperature for $24 \mathrm{~h}$. The extracts were centrifuged $(8000 \mathrm{rpm})$ for $10 \mathrm{~min}$ at room temperature. The supernatants were separated and pellets re-extracted in $7 \mathrm{~mL} \mathrm{60 \%} \mathrm{methanol} \mathrm{(v/v)} \mathrm{in} \mathrm{darkness}$ and at room temperature for $2 \mathrm{~h}$. The extracts were centrifuged under the same conditions. Similar supernatants were combined to form the total extracts, and these were concentrated to dryness by rotary evaporation and then re-dissolved in $3 \mathrm{~mL}$ methanol. Aliquots were removed for determination of the phenol content and HPLC-DAD analysis.

Total phenol contents. The amount of total phenols in the methanol foliar extracts of each sample of Quercus was determined by the Folin-Ciocalteu method (LozoyaSaldaña et al., 2007). The following values were obtained from the standard curve for gallic acid (32-260 $\mu \mathrm{g} / \mathrm{mL}$ vs. absorbance): $\mathrm{A}_{760 \mathrm{~nm}}=-0.011+0.0004$ (gallic acid) and correlation coefficient, $r=0.9989$. Absorbance values were recorded at $760 \mathrm{~nm}$ after $120 \mathrm{~min}$ of incubation at darkness. Total phenol contents were expressed as $\mathrm{mg}$ of gallic acid equivalents GAE/g dry weight (Dw).

Analysis by HPLC/DAD. The individual HPLC-DAD phenol profiles were obtained following the method described by Campos and Markham (2007). Extracts $(20 \mu \mathrm{L})$ were analysed in a Perkin Elmer Series 200 HPLC system, with a Perkin Elmer Brownlee analytical C18 column $(4.6 \times 250 \mathrm{~mm}, 5 \mu)$ and a gradient of acidified water and acetonitrile. The flow rate was $0.8 \mathrm{~mL} / \mathrm{min}$. Standard chromatograms were plotted at 280 and $340 \mathrm{~nm}$. Spectral data for all peaks were accumulated in the range of 200-400 $\mathrm{nm}$ using a diode-array detector (DAD) (Perkin Elmer Series 200). The structural information on each resolved compound was obtained by direct comparison of retention times (RT) and UV spectra with those of standards (quercetin, quercitrin, naringenin, hesperidin, epicatechin, phthalic acid, vanillic acid, gallic acid and trans-cinnamic acid) and according to the data compiled by Mabry et al. (1970) and Campos and Markham (2007). Quantitative determination of the major flavonoids was made from a stock solution of quercetin, which was prepared $(120,250$, and $500 \mu \mathrm{g} / \mathrm{mL})$ 
Table 1. Collection sites for Quercus species and hybrids

Individuals Reference number: Species

Eco-geographic information (location, latitude $\mathrm{N}$, longitude $\mathrm{W}$, altitude (masl), average temperature $\left({ }^{\circ} \mathrm{C}\right)$, annual precipitation $(\mathrm{mm})$, soil type, date

1-6 36286: $Q$. chihuahuensis, 36319: Q. chihuahuensis $\times$ grisea, 36315 Q. chihuahuensis, 36316: Q. chihuahuensis, 36321: Q. chihuahuensis and

Site I: 35 Km Durango-Mazatlán 36327: Q. chihuahuensis

Highway, 2356'08.5”, $104^{\circ} 51^{\prime} 58.3^{\prime \prime}, 2270,13,733$, eutric regosol, May 2008

7-13 36387: Q. arizonica s.l., 36515: Q. arizonica intro. grisea, 36385: Q. arizonica intro. grisea, 36419: Q. grisea, 36426: Q. arizonica s.l., 36396: Q. arizonica s.l. and 36466: Q. grisea s.l.

14-20 36410: Q. chihuahuensis, 36403: Q. undata, 36400: Q. chihuahuensis, 36401: Q. chihuahuensis, 36404: Q. undata, 36402: Q. chihuahuensis and 36394: Q. undata

21-27 36760: Q. arizonica s.l., 36739: Q. arizonica s.l., 36737: Q. arizonia s.l., 36736: Q. arizonica s.l., 36743: Q. arizonica s.l., 36725: Q. arizonica s.l. and 36726: Q. arizonica s.l

28-33 36762: Q. grisea, 36730: Q. arizonica s.l., 36784: Q. aff.arizonica, 36783: Q. aff. arizonica, 36741: Q. arizonica s.l. and 36742: Q. arizonica s.l.

Site II: 29 Km Durango-Mazatlán Highway, 23⒌'12.4”, 10451'01.5”, 2207, 14, 711, 2207, entisoil, May 2008

Site III: $13 \mathrm{Km}$ Durango-Mazatlán Highway, 2359'11.4", 10444'53.7', 2082, 16, 644, leptosol, May 2008

Site IV: $187 \mathrm{Km}$ Tepehuanes-Guanaceví Road, $25^{\circ} 28^{\prime} 25.4^{\prime \prime}, 105^{\circ} 47^{\prime} 51.5$, 2167, 14, 632, eutric regosol, Jun 2008

Site V: $191 \mathrm{Km}$ Tepehuanes-Guanaceví Road, 2529’31.4”, $105^{\circ} 47^{\prime} 11.2^{\prime \prime}, 2079$, 15, 606, eutric regosol, Jun 2008

34-40 36727: Q. arizonica s.l., 36728: Q. arizonica s.l., 36750: Q. arizonica s.l., 36780: Q. arizonica s.l., 36781: Q. arizonica s.l., 36761: Q. grisea and 36782: Q. arizonica s.l.

Site VI: 193 Km Tepehuanes-Guanaceví Road, 25³0'11.6", 10547'14.6”, 2098, 15, 611, eutric regosol, Jun 2008

41-47 38820: Q. aff. convallata, 38821: $Q$. aff. convallata, 38822: $Q$. aff. convallata, 38823: $Q$. aff. convallata intro. arizonica, 38824: $Q$. aff. convallata, 38825: $Q$. aff. convallata and 38826: $Q$. aff. convallata

Site VII: 6 Km El Tecuán-Regocijo Road, 2352'37.2”, $105^{\circ} 00^{\prime} 58.7^{\prime \prime}, 2168$, 13, 765, regosol, Jun 2008

48-54 38827: Q. aff. convallata, 38828: Q. aff. convallata, 38829: $Q$. convallata introgresión arizonica, 38830: Q. convallata, 38831: Q. convallata, 38832: Q. convallata and 38833: Q. convallata

Site VIII: $8 \mathrm{Km}$ El Tecuán-Regocijo Road, 2351'41.9", $105^{\circ} 00^{\prime} 12.9^{\prime \prime}, 2188$ 13, 773, district regosol, Jun 2008

Site IX: $10 \mathrm{Km}$ El Tecuán-Regocijo Road, 2350'54.4”, $105^{\circ} 00^{\prime} 01.6^{\circ}, 2172$, 38834: Q. aff. convallata, 38835: Q. aff. convallata, 38839: Q. arizonica s.l., and 38840: Q. aff. arizonica x convallata

13, 777, district regosol, Jun 2008

62-68 36734: Q. arizonica intro. coccolobifolia, 36733: Q. arizonica s.l. intro. coccolobifolia, 36825: Q. arizonica aff. transmontana, 36836: Q. arizonica aff. transmontana, 36837: Q. arizonica s.l., 36834: Q. arizonica aff. Transmontana and 36838: Q. arizonica s.l.

Site X: $39 \mathrm{Km}$ Durango-Mezquital, $23^{\circ} 46^{\prime} 35.6$ ', $104^{\circ} 25^{\prime} 23.7$ ', 2098, 16, 602, leptosol, Jun 2008

69-75 36860: Q. arizonica s.l., 36845: Q. arizonica s.l., 36816: Q. arizonica intro. coccolobifolia, 36788: Q. arizonica s.l., 36858: Q. arizonica aff. transmontana, 36859: Q. arizonica intro. coccolobifolia and 36843: Q. aff. arizonica x coccolobifolia

Site XI: $41 \mathrm{Km}$ Durango-Mezquital, $23^{\circ} 45^{\prime} 45.3^{\prime \prime}, 104^{\circ} 25^{\prime} 05.9^{\prime \prime}, 2043$

16, 588, leptosol, Jun 2008

76-81 36830: Q. arizonica aff. transmontana, 36835: Q. arizonica $\mathrm{x}$ coccolobifolia,

Site XII: 36 Km Durango-Mezquital 36831: Q. arizonica intro. coccolobifolia, 36735: Q. arizonica intro. coccolobifolia, Highway, $23^{\circ} 47^{\prime} 01.4^{\prime \prime}, 104^{\circ} 25^{\prime} 33.2^{\prime \prime}$, 36829: Q. arizonica intro. coccolobifolia and 36832: Q. arizonica intro. coccolobifolia 2061, 16, 593, calcium afisol, Jun 2008

for construction of the calibration curve $\left(\mathrm{A}_{280 \mathrm{~nm}}=\right.$ $413389+25881$ [quercetin], $r=0.9999$ ) by plotting the standard concentrations against the peak area in the HPLC chromatograms. The concentration of each individual compound was expressed in $\mu \mathrm{g}$ of quercetin equivalents (EQ quercetin $\mu \mathrm{g} / \mathrm{g}$ Dw) (here $395.9 \mu \mathrm{g} / \mathrm{g}$ Dw).
Data analysis. The individual phenol profiles comprised of all compounds detected in the respective HPLC-DAD chromatograms. Each compound was treated as a single chemical character and assessed in a binary matrix coded by 1 (presence) or 0 (absence) in each population. A dendrogram obtained from a cluster analysis (Ward's method) based on chemical marker data was calculated 
using PAST 1.43 (Hammer et al., 2001). Because phenolic contents were not normally distributed, the non-parametric Kruskal-Wallis test was used to evaluate intra and inter-specific variability of these compounds either at the quantitative or the qualitative levels (Kruskal and Wallis, 1952). The test was performed with the NPAR1WAY procedure of SAS/ETS ${ }^{\circledR}$ (SAS Institute Inc., 2004).

\section{Results and Discussion}

Quercus foliar phenolic compounds. A total of 73 compounds were determined by HPLC-DAD analysis of the leaves of the species under study (Table 2). The analysis revealed 20 phenolic acids and 53 flavonoids. The flavonoids present in the foliar tissues included 34 flavonols, 5 flavones, 4 dihydroflavonoids and 10 un-identified flavonoids. The flavonols included seven quercetin derivatives, four myricetin derivatives, seven kaempferol derivatives and two isorhamnetin derivatives. The flavones included two tricitin derivatives and one luteolin derivative. Compounds $\mathrm{f} 13$ (quercetin glycoside), f 31 (isorhamnetin glycoside) and $\mathrm{f} 37$ (kaempferol glycoside) were the most abundant phenolic compounds. The results of the present study are consistent with those

Table 2. Retention time and $\lambda_{\max }$ of the phenolic compounds present in the foliar tissues of the analysed Quercus species

\begin{tabular}{|c|c|c|c|}
\hline $\begin{array}{l}\text { Com- } \\
\text { pound }\end{array}$ & $\begin{array}{l}\text { Identi- } \\
\text { fication }\end{array}$ & $\begin{array}{l}\text { Retention } \\
\text { time }(\min )^{*}\end{array}$ & $\lambda_{\max }(\mathrm{nm})$ \\
\hline f01 & $\mathrm{F} 1$ & $36.40 \pm 0.00$ & 255,360 \\
\hline $\mathrm{f} 02$ & $\mathrm{Fl}$ & $37.87 \pm 0.00$ & 255,360 \\
\hline f03 & $\mathrm{U}$ & $41.83 \pm 0.00$ & 280,360 \\
\hline f04 & Qg & $44.18 \pm 0.00$ & $255,299 \mathrm{sh}, 350$ \\
\hline f05 & $\mathrm{Fl}$ & $63.12 \pm 0.17$ & 255,370 \\
\hline f06 & $\mathrm{Fl}$ & $67.72 \pm 0.27$ & $250,301 \mathrm{sh}, 370$ \\
\hline f07 & $\mathrm{F} 1$ & $68.50 \pm 0.31$ & 255,367 \\
\hline f08 & $\mathrm{Fl}$ & $68.46 \pm 0.22$ & $265,285 \mathrm{sh}, 355$ \\
\hline f09 & $\mathrm{F} 1$ & $69.59 \pm 0.31$ & 255,360 \\
\hline f10 & Qg & $69.97 \pm 0.00$ & $255,294 \mathrm{sh}, 355$ \\
\hline f11 & $\mathrm{Lg}$ & $70.07 \pm 0.00$ & $265,295 \mathrm{sh}, 360$ \\
\hline $\mathrm{f} 12$ & $\mathrm{U}$ & $70.27 \pm 0.44$ & $265,290 \mathrm{sh}, 355$ \\
\hline f13 & Qg & $70.65 \pm 0.27$ & $252,290 \mathrm{sh}, 350$ \\
\hline f14 & $\mathrm{Mg}$ & $70.81 \pm 0.00$ & $253,265 \mathrm{sh}, 299 \mathrm{sh}, 353$ \\
\hline f15 & $\mathrm{U}^{0}$ & $71.50 \pm 0.36$ & $253,270 \mathrm{sh}, 360$ \\
\hline f16 & Qg & $72.60 \pm 0.26$ & $255,300 \mathrm{sh}, 360$ \\
\hline f17 & $\mathrm{Df}$ & $72.56 \pm 0.30$ & 280 \\
\hline f18 & $\mathrm{Td}$ & $72.91 \pm 0.01$ & $266,293 \mathrm{sh}, 350$ \\
\hline f19 & $\mathrm{U}$ & $72.97 \pm 0.00$ & 265,350 \\
\hline $\mathrm{f} 20$ & $\mathrm{U}$ & $73.43 \pm 0.26$ & $266,297 \mathrm{sh}, 353$ \\
\hline
\end{tabular}

continued next column $\rightarrow$

\begin{tabular}{|c|c|c|c|}
\hline $\begin{array}{l}\text { Com- } \\
\text { pound }\end{array}$ & $\begin{array}{l}\text { Identi- } \\
\text { fication }\end{array}$ & $\begin{array}{l}\text { Retention } \\
\text { time }(\min )^{*}\end{array}$ & $\lambda_{\text {max }}(\mathrm{nm})$ \\
\hline $\mathrm{f} 21$ & $\mathrm{Fl}$ & $74.43 \pm 0.25$ & $254,305 \mathrm{sh}, 364$ \\
\hline $\mathrm{f} 22$ & $\mathrm{Kg}$ & $74.76 \pm 0.13$ & 260,350 \\
\hline $\mathrm{f} 23$ & U & $74.82 \pm 0.16$ & $267,285 \mathrm{sh}, 360$ \\
\hline $\mathrm{f} 24$ & Qg & $75.27 \pm 0.21$ & $256,300 \mathrm{sh}, 357$ \\
\hline $\mathrm{f} 25$ & $\mathrm{Mg}$ & $75.66 \pm 0.33$ & $255,297 \mathrm{sh}, 352$ \\
\hline $\mathrm{f} 26$ & $\mathrm{Fl}$ & $75.17 \pm 0.00$ & 267,360 \\
\hline $\mathrm{f} 27$ & $\mathrm{Tg}$ & $75.66 \pm 0.22$ & $250,262 \mathrm{sh}, 353$ \\
\hline $\mathrm{f} 28$ & $\mathrm{Fl}$ & $75.66 \pm 0.00$ & 250,360 \\
\hline $\mathrm{f} 29$ & Qg & $76.44 \pm 0.39$ & $256,266 \mathrm{sh}, 292 \mathrm{sh}, 356$ \\
\hline $\mathrm{f} 30$ & $\mathrm{U}$ & $76.43 \pm 0.18$ & 270,357 \\
\hline f31 & $\operatorname{Ig}$ & $76.56 \pm 0.36$ & $255,267 \mathrm{sh}, 355$ \\
\hline $\mathrm{f} 32$ & $\mathrm{Ig}$ & $77.18 \pm 0.00$ & $255,267 \mathrm{sh}, 355$ \\
\hline f33 & $\mathrm{U}$ & $77.50 \pm 0.36$ & $267,285 \mathrm{sh}, 356$ \\
\hline $\mathrm{f} 34$ & Df & $77.74 \pm 0.09$ & 281 \\
\hline f35 & $\mathrm{Fl}$ & $78.93 \pm 0.05$ & $266,296 \mathrm{sh}, 351$ \\
\hline f36 & $\mathrm{U}$ & $78.72 \pm 0.21$ & $255,269 \mathrm{sh}, 355$ \\
\hline f37 & $\mathrm{Kg}$ & $78.74 \pm 0.32$ & 265,350 \\
\hline f38 & $\mathrm{Fl}$ & $80.13 \pm 0.15$ & 267,350 \\
\hline f39 & $\mathrm{Kg}$ & $80.62 \pm 0.36$ & 266,351 \\
\hline $\mathrm{f} 40$ & $\mathrm{U}$ & $80.43 \pm 0.00$ & $270,287 \mathrm{sh}, 361$ \\
\hline $\mathrm{f} 41$ & $\mathrm{Kg}$ & $81.45 \pm 0.42$ & 265,295 sh, 349 \\
\hline $\mathrm{f} 42$ & $\mathrm{Df}$ & $81.02 \pm 0.00$ & 278 \\
\hline $\mathrm{f} 43$ & $\mathrm{Mg}$ & $81.07 \pm 0.00$ & $255,267 \mathrm{sh}, 297 \mathrm{sh}, 354$ \\
\hline $\mathrm{f} 44$ & $\mathrm{Mg}$ & $82.06 \pm 0.03$ & $256,300 \mathrm{sh}, 351$ \\
\hline $\mathrm{f} 45$ & Qg & $82.48 \pm 0.37$ & $256,267 \mathrm{sh}, 300 \mathrm{sh}, 351$ \\
\hline f46 & $\mathrm{Kg}$ & $82.15 \pm 0.25$ & 265,351 \\
\hline $\mathrm{f} 47$ & $\mathrm{Kg}$ & $83.89 \pm 0.04$ & 266,350 \\
\hline $\mathrm{f} 48$ & $\mathrm{Df}$ & $88.25 \pm 0.31$ & 281 \\
\hline f49 & $\mathrm{Ca}$ & $89.50 \pm 0.00$ & 287,311 \\
\hline $\mathrm{f} 50$ & $\mathrm{~F}$ & $89.47 \pm 0.00$ & 266,294 sh, 314 \\
\hline f51 & $\mathrm{Pa}$ & $93.46 \pm 0.07$ & 267,316 \\
\hline $\mathrm{f} 52$ & $\mathrm{~Pa}$ & $96.95 \pm 0.00$ & 267,311 \\
\hline f53 & $\mathrm{F} 1$ & $101.37 \pm 0.00$ & 266,364 \\
\hline f54 & $\mathrm{Fl}$ & $103.08 \pm 0.01$ & 256,370 \\
\hline $\mathrm{f} 55$ & $\mathrm{Kg}$ & $103.10 \pm 0.12$ & 264,364 \\
\hline f56 & $\mathrm{Pa}$ & $104.66 \pm 0.42$ & 266,314 \\
\hline f57 & $\mathrm{F}$ & $105.63 \pm 0.00$ & $266,297 \mathrm{sh}, 313$ \\
\hline f58 & $\mathrm{Pa}$ & $108.57 \pm 0.21$ & 267,314 \\
\hline f59 & $\mathrm{Pa}$ & $109.31 \pm 0.24$ & 267,312 \\
\hline f60 & $\mathrm{Pa}$ & $110.35 \pm 0.34$ & 267,311 \\
\hline f61 & $\mathrm{Pa}$ & $111.37 \pm 0.26$ & 267,312 \\
\hline f62 & $\mathrm{Pa}$ & $112.40 \pm 0.29$ & 267,314 \\
\hline f63 & $\mathrm{Pa}$ & $113.30 \pm 0.25$ & 266,311 \\
\hline f64 & $\mathrm{Pa}$ & $114.11 \pm 0.05$ & 266,311 \\
\hline f65 & $\mathrm{Pa}$ & $115.47 \pm 0.06$ & 266,311 \\
\hline f66 & $\mathrm{Pa}$ & $116.60 \pm 0.30$ & 268,311 \\
\hline f67 & $\mathrm{Pa}$ & $117.50 \pm 0.32$ & 267,312 \\
\hline f68 & $\mathrm{Pa}$ & $118.52 \pm 0.34$ & 267,312 \\
\hline f69 & $\mathrm{Pa}$ & $119.52 \pm 0.33$ & 266,313 \\
\hline $\mathrm{f} 70$ & $\mathrm{~Pa}$ & $120.42 \pm 0.26$ & 267,315 \\
\hline $\mathrm{f} 71$ & $\mathrm{~Pa}$ & $121.53 \pm 0.04$ & 267,313 \\
\hline $\mathrm{f} 72$ & $\mathrm{~Pa}$ & $122.35 \pm 0.21$ & 266,314 \\
\hline $\mathrm{f} 73$ & $\mathrm{~Pa}$ & $123.52 \pm 0.39$ & 266,311 \\
\hline
\end{tabular}

*Retention times are mean values and standard deviations for 1-81 independent samples; $\mathrm{Ca}=$ cinnamic acid; $\mathrm{Df}=$ dihydraflavonoid; $\mathrm{F}$ = flavone; $\mathrm{Fl}=$ flavonel; $\mathrm{Ig}$ = isorhamnetin glycoside; $\mathrm{Kg}=$ kaempferol glycoside; $\mathrm{Lg}=$ lutheolin glycoside; $\mathrm{Mg}=$ myricetin glycoside; $\mathrm{Pa}=$ phenolic acid; $\mathrm{Qg}=$ quercetin glycoside; $\mathrm{Td}=$ tricitin derivative; $\mathrm{Tg}=$ tricin glycoside; $\mathrm{U}=$ unidentified. 
reported by Karioti et al. (2011) who also identified kaempferol glycosides, isorhamnetin glycosides and quercetin glycosides as the most abundant phenolic compounds in extracts of Quercus ilex trichomes. Rivas-Arreola et al. (2010) and Wang et al. (2010) also identified kaempferol glycosides and quercetin glycosides as the most abundant phenolic compounds in other species of Quercus. The most complex foliar phenol profile was that of $Q$. chihuahuensis, which included 30 phenols. The least complex profile was that of $Q$. arizonica intro. coccolobifolia, with 6 phenols.

Total phenolic contents. Table 3 shows the average total foliar phenolic contents of the species of Quercus analysed. According to the non-parametric Kruskal-Wallis test, the total phenol contents varied significantly among Quercus species $(\mathrm{H}=28.48, \mathrm{P}=0.0002)$ (Table 4). A comparison

Table 3. Average total foliar phenolic contents (gallic acid equivalents) of Quercus grisea, Q. arizonica s.l., $Q$. chihuahuensis, $Q$. undata, $Q$. arizonica intro. coccolobifolia, $Q$. arizonica aff. transmontana, $Q$. aff. convallata, and $Q$. convallata

\begin{tabular}{llll}
\hline \hline Site & Tree species & $\begin{array}{l}\text { No. of } \\
\text { indivi- } \\
\text { duals }\end{array}$ & $\begin{array}{l}\text { Average } \\
\text { total } \\
\text { concen- } \\
\text { tration }\end{array}$ \\
& & & 369.74 \\
I & Q. chihuahuensis & 5 & 340.00 \\
II & Q. arizonica s.l. & 3 & 367.50 \\
II & Q. grisea & 1 & 280.30 \\
III & Q. chihuahuensis & 4 & 299.97 \\
III & Q. undata & 3 & 399.61 \\
IV & Q. arizonica s.l. & 7 & 313.73 \\
V & Q. arizonica s.l. & 3 & 311.20 \\
V & Q. grisea & 1 & 295.62 \\
VI & Q. arizonica s.l. & 6 & 281.20 \\
VI & Q. grisea & 1 & 259.97 \\
VII & Q. aff. convallata & 6 & 198.75 \\
VIII & Q. aff. convallata & 2 & 198.73 \\
VIII & Q. convallata & 4 & 208.73 \\
IX & Q. aff. convallata & 3 & 196.85 \\
IX & Q. arizonica s.l. & 2 & 239.97 \\
X & Q. arizonica aff. transmontana & 3 & 255.00 \\
X & Q. arizonica intro coccolobifolia & 1 & 232.45 \\
X & Q. arizonica s.l. & 2 & 213.70 \\
XI & Q. arizonica aff. transmontana & 1 & 210.00 \\
XI & Q. arizonica intro coccolobifolia & 2 & 221.23 \\
XI & Q. arizonica s.l. & 3 & 247.50 \\
XII & Q. arizonica aff. transmontana & 1 & 273.75 \\
XII & Q. arizonica intro coccolobifolia & 4 & \\
\hline \hline & & & \\
\hline
\end{tabular}

among groups of individuals belonging to the same Quercus species and that were growing in different sites showed that locality also affected phenol contents of the $(\mathrm{H}=62.69, \mathrm{P}<0.0001)$, suggesting variation in phenolic compounds within tree species and localised environmental control of levels of these compounds. As an example phenol contents of $Q$. arizonica s.l. which was recorded in sites II, II, IV, V, VI, IX, X and XI varied significantly in 6 of the 7 pair comparisons tested using the individuals of site II as the reference group. These results could be explained by the effect of site variability in soil composition, temperature, and rainfall (Borges et al., 2013; Gobbo-Neto and Lopes, 2007; Monteiro et al., 2006). The lowest average level (196.85 mg/g Dw) was estimated for individuals of Q. convallata (site IX) and the highest average level (399.61 mg/g Dw) for Q. arizonica s.l. (site IV).

Results of the non parametric Kruskal-Wallis test among studied Quercus species are shown in Table 4. Significant differences $(\mathrm{P}<0.05)$ between foliar phenol levels were observed in 16 of 28 pair comparisons. The foliar phenol contents were highest in Quercus arizonica s.l. and Q. chihuahuensis and lowest in Q. arizonica aff. transmontana, $Q$. convallata and $Q$. aff. convallata. The foliar phenol contents estimated for the species of Quercus analysed in the present study are similar to the levels reported by Karageorgou and Mantas (2006), who estimated levels ranging from 50 to $550 \mathrm{mg} / \mathrm{g} \mathrm{Dw}$ in the leaves of $Q$. coccifera L., and by Rivas-Arreola et al. (2010), who estimated levels ranging from 227 to $537 \mathrm{mg} / \mathrm{g}$ Dw in the leaves of another species of Quercus.

Individual phenolic concentration. The relative concentrations of the individual phenolic compounds detected in each sample are shown in Table 5. The Kruskal-Wallis test revealed statistically significant differences between the relative concentrations of phenolic compounds in several samples (Table 6). The maximum concentration observed was that of compound f $08(385.86 \mu \mathrm{g} / \mathrm{g} \mathrm{Dw})$ in $Q$. chihuahuensis (sample 1), and the lowest concentration was that of compound f $72(37.21 \mu \mathrm{g} / \mathrm{g} \mathrm{Dw})$ in Q. arizonica intro. coccolobifolia (sample 71).

As shown in Table 6, highly significant differences were observed in the mean relative concentrations of 
Table 4. Results of the Kruskal-Wallis test for paired comparisons of foliar phenol contents in the analysed Quercus species

\begin{tabular}{|c|c|c|}
\hline Pairs of species compared (mean score in brackets) & $\mathrm{H}$ & $\operatorname{Pr}>\mathrm{H}$ \\
\hline Q. chihuahuensis (19.38) - Q. arizonica s.l. (17.51) & 0.22 & 0.636 \\
\hline Q. chihuahuensis (6.61) - Q. grisea (6.16) & 0.03 & 0.853 \\
\hline Q. chihuahuensis (6.88) - Q. undata (5.33) & 0.42 & 0.516 \\
\hline Q. chihuahuensis (15.27) - Q. aff. convallata (6.59) & 10.68 & $0.001 * *$ \\
\hline Q. chihuahuensis (9.00) - Q. convallata (2.50) & 7.73 & $0.005 * *$ \\
\hline Q. chihuahuensis (11.16) - Q. arizonica intro. coccolobifolia (5.07) & 6.46 & $0.011 *$ \\
\hline Q. chihuahuensis (10.0) - Q. arizonica aff. transmontana (3.0) & 9.00 & $0.002 * *$ \\
\hline Q. arizonica s.l. (14.94) - Q. grisea (15.50) & 0.01 & 0.914 \\
\hline Q. arizonica s.l. (15.15) - Q. undata (13.66) & 0.08 & 0.774 \\
\hline Q. arizonica s.l. (22.46) - Q. aff. convallata (10.81) & 8.95 & $0.002 * *$ \\
\hline Q. arizonica s.l. (17.26) - Q. convallata (4.00) & 7.88 & $0.0050 * *$ \\
\hline Q. arizonica s.l. (18.75) - Q. arizonica intro. coccolobifolia (10.50) & 4.02 & $0.044 *$ \\
\hline Q. arizonica s.l. (17.46) - Q. arizonica aff. transmontana (8.40) & 4.17 & $0.041 *$ \\
\hline Q. grisea (4.0) - Q. undata (3.0) & 0.483 & 0.486 \\
\hline Q. grisea (12.83) - Q. aff. convallata (6.04) & 6.21 & $0.012 *$ \\
\hline Q. grisea $(6.00)-Q$. convallata $(2.50)$ & 5.58 & $0.0323 *$ \\
\hline Q. grisea (8.33) - Q. arizonica intro. coccolobifolia (4.28) & 3.75 & 0.0527 \\
\hline Q. grisea (7.0) - Q. arizonica aff. transmontana (3.0) & 5.00 & $0.025^{*}$ \\
\hline Q. undata (12.50) - Q. aff. convallata (6.13) & 5.47 & $0.0193 *$ \\
\hline Q. undata (6.00) - Q. convallata (2.50) & 4.66 & $0.030 *$ \\
\hline Q. undata (8.33) - Q. arizonica intro. coccolobifolia (4.28) & 3.77 & 0.052 \\
\hline Q. undata (7.0) - Q. arizonica aff. transmontana (3.0) & 5.06 & $0.0245^{*}$ \\
\hline$Q$. aff. convallata $(9.27)-Q$. convallata $(4.50)$ & 3.34 & 0.067 \\
\hline Q. aff. convallata (8.45) - Q. arizonica intro. coccolobifolia (11.14) & 1.08 & 0.297 \\
\hline Q. aff. convallata (8.31) - Q. arizonica aff. transmontana (8.90) & 0.051 & 0.820 \\
\hline Q. convallata (3.25) - Q. arizonica intro. coccolobifolia (7.57) & 4.34 & $0.037 *$ \\
\hline Q. convallata (3.00) - Q. arizonica aff. transmontana (6.60) & 3.93 & $0.047 *$ \\
\hline Q. arizonica intro. coccolobifolia (7.35) - Q. arizonica aff. transmontana (5.30) & 0.95 & 0.329 \\
\hline
\end{tabular}

*significant differences; **highly significant differences.

phenols between the following pairs of Quercus species: $Q$. aff. convallata and $Q$. arizonica s.l.; $Q$. aff. convallata and $Q$. chihuahuensis; $Q$. arizonica intro. coccolobifolia and $Q$. convallata; $Q$. chihuahuensis and $Q$. convallata. The tree species Quercus grisea, Q. chihuahuensis, Q. arizonica s.l. and $Q$. undata accumulated the highest relative concentrations of phenols, whereas $Q$. aff. convallata and $Q$. arizonica aff. transmontana accumulated the lowest levels.

In summary, phenolic concentrations of studied white oak tree species varied greatly among, species, individuals, and sites. This is in agreement with previous studies on phenolic contents. Significant variation in phenolic concentrations has been reported among tissue types in an individual, among sites, and between species (Van Alstyne et al., 1999, Rivas-Arreola et al., 2010).
The results indicate that Quercus species contain larger amounts of phenol compounds than most of the other plants. Rivas-Arreola et al. (2010) reported phenolic contents of $537 \mathrm{mg} / \mathrm{g}, 331 \mathrm{mg} / \mathrm{g}$ and $227 \mathrm{mg} / \mathrm{g}$ in dried leaves of Quercus sideroxyla, Quercus eduardii and Quercus resinosa, respectively. Amarowicz et al. (2004) reported phenolic contents of $55.4,58$, and $67.6 \mathrm{mg} / \mathrm{g}$ in dried seeds of red bean (Phaseolus vulgaris), red lentil (Lens culinaris) and green lentil (Lens culinaris), respectively. Marinova et al. (2005) reported total phenolic contents of 3.03, 4.29, 3.55 and $6.70 \mathrm{mg} / \mathrm{g}$ in fruits of plum (Prunus domestica), sour cherry (Prunus cerasus), blackberry (Rubus coesins) and blueberry (Vaccinium myrtilus), respectively.

Cluster analysis. The results of the cluster analysis of the foliar phenol profiles of the individuals analysed 
Table 5. Relative concentrations of the individual phenolic compounds identified in the leaves of the Quercus species under study (quercetin equivalents)

\begin{tabular}{|c|c|c|c|c|c|c|c|c|}
\hline \multirow{2}{*}{$\begin{array}{l}\text { Com- } \\
\text { pound }\end{array}$} & \multicolumn{8}{|c|}{ Relative concentration $(\mu \mathrm{g} / \mathrm{g} \mathrm{Dw})$} \\
\hline & Q. grisea & Q. arizonica s.l. & Q. chihuahuensis & Q. undata & $\begin{array}{l}\text { Q. arizonica intro. } \\
\text { coccolobifolia }\end{array}$ & $\begin{array}{l}\text { Q. arizonica aff. } \\
\text { transmontana }\end{array}$ & Q. aff. convallata & Q. convallata \\
\hline f05 & 71.2 & 76 & - & - & - & - & - & 69.6 \\
\hline f06 & 323.84 & 302.12 & 285 & 306.42 & 98.18 & 96.59 & - & 80.76 \\
\hline $\mathrm{f07}$ & - & - & - & - & 152.55 & - & - & - \\
\hline f08 & 300.88 & - & 385.86 & - & 212.20 & - & 203.49 & - \\
\hline f09 & - & 344.43 & - & - & 167.86 & - & - & 69.28 \\
\hline $\mathrm{f} 12$ & 362.64 & 336.15 & - & - & 66.51 & - & - & \\
\hline f13 & - & 214.73 & 330.37 & - & - & - & 66.51 & 67.30 \\
\hline f15 & - & 289.64 & 145.29 & - & 120.35 & 120.35 & - & - \\
\hline f17 & 227.24 & 306.95 & - & - & 216.16 & - & - & - \\
\hline $\mathrm{f} 20$ & - & - & - & - & 100.29 & - & - & - \\
\hline $\mathrm{f} 21$ & - & 309.59 & - & 318.30 & 184.09 & 193.72 & 184.09 & 179.73 \\
\hline $\mathrm{f} 22$ & - & 160.73 & 146.22 & 142.52 & - & - & - & - \\
\hline $\mathrm{f} 23$ & - & 193.19 & - & - & - & 187.65 & 180.13 & - \\
\hline $\mathrm{f} 24$ & - & - & - & 102.14 & - & 100.55 & 71.26 & 60.96 \\
\hline $\mathrm{f} 25$ & - & - & - & - & - & - & 146.74 & - \\
\hline $\mathrm{f} 27$ & - & 145.69 & - & - & - & - & 95.80 & 62.55 \\
\hline f29 & 213.78 & 239.91 & - & - & 148.85 & - & - & - \\
\hline $\mathrm{f} 31$ & - & 306.95 & 174.98 & - & - & - & 128.46 & 58.59 \\
\hline $\mathrm{f} 34$ & - & 313.02 & - & - & - & - & - & - \\
\hline f36 & - & 139.35 & 124.31 & - & - & 63.34 & - & - \\
\hline f37 & - & 153.41 & 146.87 & - & 72.84 & 101.54 & 55.42 & - \\
\hline f39 & - & 64.13 & - & - & 59.38 & 58.59 & 46.71 & - \\
\hline f45 & - & - & - & - & - & - & 43.81 & - \\
\hline $\mathrm{f} 46$ & - & - & - & 70.47 & - & 63.34 & 58.85 & 50.41 \\
\hline f55 & - & 67.46 & - & - & - & - & - & - \\
\hline f58 & - & 69.10 & 66.51 & - & - & - & - & - \\
\hline f59 & 71.26 & 84.72 & 99.76 & - & - & - & - & - \\
\hline f60 & - & 67.3 & 72.05 & - & - & - & - & - \\
\hline f61 & 57.8 & 61.36 & 82.34 & - & - & - & - & - \\
\hline f62 & - & - & 59.38 & - & - & 52.25 & 45.92 & - \\
\hline f63 & - & 62.81 & - & - & 46.71 & - & - & - \\
\hline$f 65$ & - & 62.29 & - & - & - & 53.05 & - & - \\
\hline f66 & 62.55 & 84.19 & - & 67.30 & - & 55.42 & 49.48 & - \\
\hline f67 & 57 & - & 67.30 & - & - & - & - & - \\
\hline f68 & - & 62.55 & - & 49.09 & - & - & - & - \\
\hline f69 & - & 58.59 & - & - & 44.73 & - & - & - \\
\hline f70 & - & 57.14 & - & - & - & - & - & 42.75 \\
\hline $\mathrm{f} 72$ & - & 45.76 & - & - & 37.21 & - & - & - \\
\hline $\mathrm{f} 73$ & - & 43.15 & - & - & - & - & - & - \\
\hline
\end{tabular}

are shown in Fig. 1. Two main groups can be distinguished: group I, formed by subgroups $\mathrm{A}$ and $\mathrm{B}$, and group II, by subgroups C, D, E, F. Clade I excluded samples from sites $2,4,5,6$, and 12 , which mainly included specimens of Quercus arizonica s.l. and Q. arizonica intro. coccolobifolia. Clade II excluded samples from site 9, which comprised samples of $Q$. aff. convallata and $Q$. arizonica s. l. All subgroups were heterogeneous, except subgroup $C$, which included three samples of the same taxa, $Q$. arizonica intro. coccolobifolia from site 12. A third of the samples of Q. chihuahuensis were grouped in subgroup A, from 
Table 6. Results of the Kruskal-Wallis test for paired comparisons of samples to assess differences in the relative concentrations of phenolic compound in the leaves of the Quercus species under study

\begin{tabular}{|c|c|c|}
\hline Pairs of species compared & $\mathrm{H}$ & $\operatorname{Pr}>\mathrm{H}$ \\
\hline Q. aff.convallata (33.07) -Q. arizonica intro. coccolobifolia (41.87) & 3.02 & 0.0821 \\
\hline Q. aff. convallata (59.51) -Q. arizonica s.l. (80.84) & 7.65 & $0.0057 * *$ \\
\hline Q. aff. convallata (30.25) -Q. arizonica aff. transmontana (34.55) & 0.72 & 0.3936 \\
\hline Q. aff. convallata (32.61) -Q. chihuahuensis (48.41) & 9.32 & $0.0023 * *$ \\
\hline Q. aff. convallata (31.54) -Q. convallata (27.62) & 0.59 & 0.4418 \\
\hline Q. aff. convallata (25.32) -Q. grisea (38.68) & 6.11 & $0.0134 *$ \\
\hline Q. aff. convallata (26.62) -Q. undata (33.50) & 1.62 & 0.2029 \\
\hline Q. arizonica intro. coccolobifolia (65.89) -Q. arizonica s.l. (66.66) & 0.00 & 0.9246 \\
\hline Q. arizonica intro. coccolobifolia (25.12) - Q. arizonica aff. transmontana (20.97) & 1.04 & 0.3057 \\
\hline Q. arizonica intro. coccolobifolia (29.37) -Q. chihuahuensis (33.25) & 0.70 & 0.3999 \\
\hline Q. arizonica intro. coccolobifolia (26.48) - Q. convallata (15.53) & 7.4 & $0.0065 * *$ \\
\hline Q. arizonica intro. coccolobifolia (18.71) - Q. grisea (23.27) & 1.26 & 0.2611 \\
\hline Q. arizonica intro. coccolobifolia (20.35) -Q. undata (19.09) & 0.09 & 0.7549 \\
\hline Q. arizonica s.l. (62.66) -Q. arizonica aff. transmontana (54.75) & 0.76 & 0.3803 \\
\hline Q. arizonica s.l. (66.19) -Q. chihuahuensis (79.61) & 2.89 & 0.0891 \\
\hline Q. arizonica s.l. (63.65) - Q. convallata (39.96) & 6.43 & $0.0112 *$ \\
\hline Q. arizonica s.l. (57.14) -Q. grisea (66.09) & 0.71 & 0.3973 \\
\hline Q. arizonica s.l. (57.75) -Q. undata (60.36) & 0.06 & 0.8047 \\
\hline Q. arizonica aff. transmontana (20.36) -Q. chihuahuensis (29.75) & 4.51 & $0.0335^{*}$ \\
\hline Q. arizonica aff. transmontana (20.36) -Q. convallata (29.75) & 4.57 & $0.0324 *$ \\
\hline Q. arizonica aff. transmontana (13.27) -Q. grisea (17.81) & 1.94 & 0.1634 \\
\hline Q. arizonica aff. transmontana (14.55) -Q. undata (15.72) & 0.12 & 0.7191 \\
\hline Q. chihuahuensis (30.57) -Q. convallata (14.71) & 12.87 & $0.0003 * *$ \\
\hline Q. chihuahuensis (23.26) -Q. grisea (22.18) & 0.05 & 0.8121 \\
\hline Q. chihuahuensis (24.45) -Q. undata (18.50) & 1.71 & 0.1910 \\
\hline Q. convallata (10.87) -Q. grisea (18.54) & 6.09 & $0.0136^{*}$ \\
\hline Q. convallata (11.40) -Q. undata (17.77) & 4.20 & $0.0404 *$ \\
\hline Q. grisea (12.22) -Q. undata (10.77) & 0.27 & 0.5988 \\
\hline
\end{tabular}

*significant difference; **highly significant difference.

sites 1 and 3. Subgroup B mainly comprised samples of $Q$. aff. convalata from sites 7,8 and 9 , and Q. arizonica s.l. from sites 9 and 10. Subgroup D comprised samples of Q. arizonica s.l. from sites 2, 4, 5 and 6. Subgroup E included the samples of $Q$. arizonica intro. coccolobifolia from sites 10 and 11, and subgroup F included two samples of the same taxa $Q$. arizonica intro. grisea from site 2 and $Q$. arizonica s.l. from site 4. Despite the species-specific tendency reported for phenol profiles (Almaraz-Abarca et al., 2006; Veit et al., 1995), the species of Quercus analysed in the present study were not clearly distinguished by their phenol profiles.

\section{Conclusion}

The phenols synthesised by foliar tissues of the species of Quercus analysed here are diverse and some of the profiles are complex (e.g., that of Q. chihuahuensis). The compounds are produced in different ways and can reach very high concentrations. The variability in the phenol composition and the amounts of those compounds in the leaves hampered identification of some trends in the patterns of accumulation. This is the first report on the quantitative and qualitative composition of foliar phenolic compounds in selected Quercus tree species of Mexico. Further chemo-taxonomic studies including the analysis of terpenoid profiles in other types of tissues may yield more conclusive results.

\section{Acknowledgement}

The authors are grateful to Socorro González Elizondo for help with taxonomical identification of the samples. One of the authors is grateful to the Comisión de Fomento 


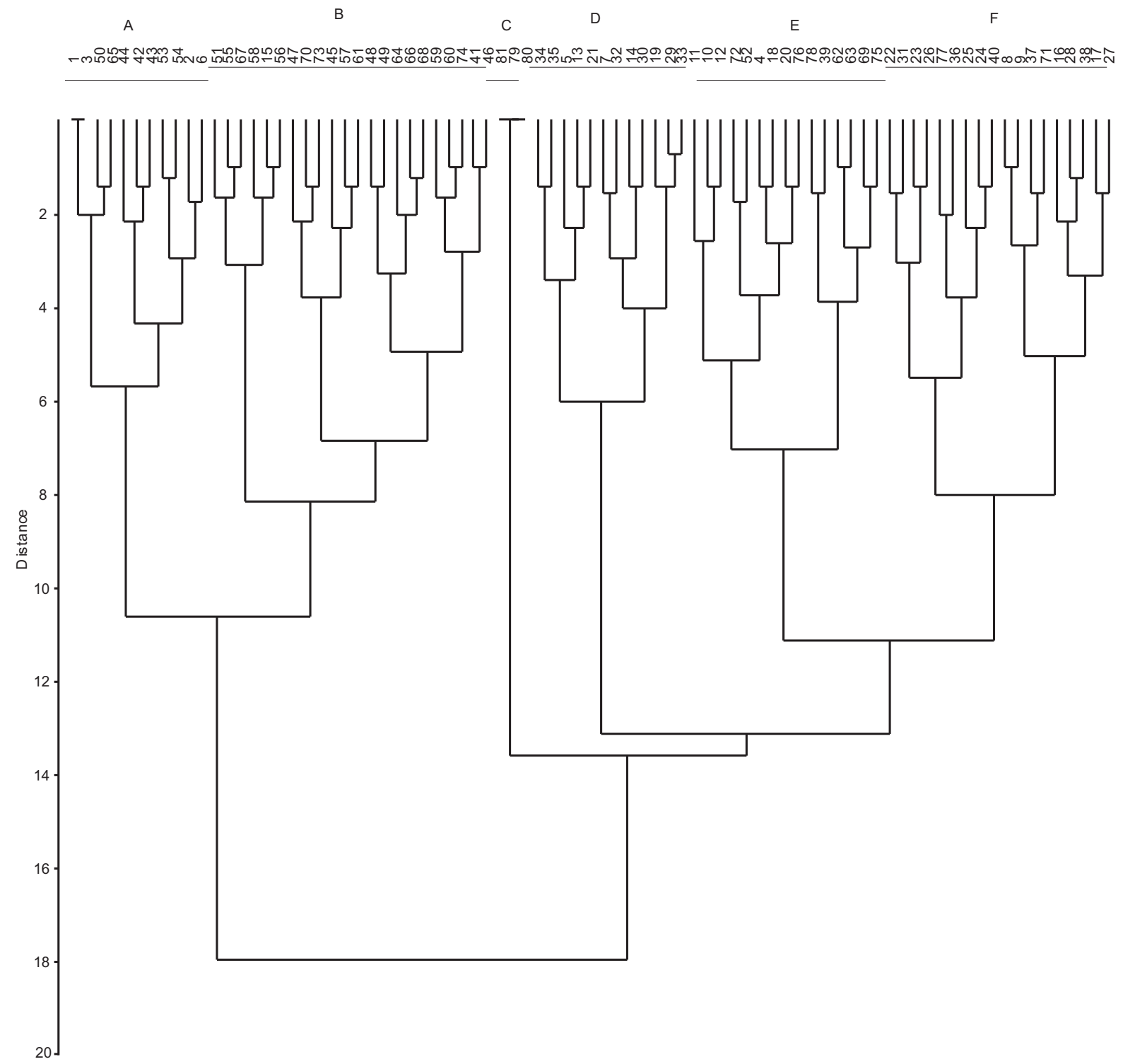

Fig. 1. Results of cluster analysis comparing foliar phenol profiles of 81 specimens of Quercus arizonica s.l., $Q$. chihuahuensis, $Q$. grisea, $Q$. undata, $Q$. arizonica intro. coccolobifolia, $Q$. arizonica aff. transmontana, $Q$. convallata and $Q$. aff. convallata. The numbers of the samples correspond to those shown in Table 1.

a las Actividades Académicas del Instituto Politécnico Nacional (COFAA IPN) for research funding. We are also grateful to two anonymous reviewers for their guidance in correcting the manuscript.

\section{References}

Abdala, L.R., Seeligmann, P. 1995. Flavonoids in Tagetes zipaquirensis and their chemosystematic significance. Biochemical Systematics and Ecology, 23: 871-872.

Almaraz-Abarca, N., Campos, M.G., Delgado-Alvarado,
A., Ávila-Reyes, J.A., Naranjo-Jiménez, N., Herrera-Corral, J., Tomatas, A.F., Almeida, A.J., Vieira, A. 2007. Fenoles del polen de Stenocactus, echinocereus y Mammillaria (Cactaceae). Polibotánica, 23: 37-55.

Almaraz-Abarca, N., González-Elizondo, M.S., TenaFlores, J.A., Ávila-Reyes, J.A., Herrera-Corral, J., Naranjo-Jiménez, N., 2006. Foliar flavonoids distinguish Pinus leiophylla and Pinus chihuahuana (Confierales: Pinaceae). Proceedings of the Biological Society of Washington, 119: 426-436. 
Amarowicz, R., Troszyñska, A., Barylko-Pikielna, N., Shahidi, F. 2004. Polyphenolics extracts from legume seeds: correlations between total antioxidant activity, total phenolics content, tannins content and astringency. Journal of Food Lipids, 11: 278286.

Bangou, M.J., Almaraz-Abarca, N., Méda, N.T.R., Zeba, B., Kiendrebéogo, M., Millogo-Rasolodimby, J., Nacoulma, O.G. 2011. Polyphenolic composition of Lantana camara and Lippia chevalieri, and their antioxidant and antimicrobial activities. International Journal of Phytomedicine, 4: 115-124.

Borazan, A., Babaç, M.T. 2003. Morphometric leaf variation in oaks (Quercus) of Bolu, Turkey. Annales Botanici Fennici, 40: 233-242.

Borges, L.L., Alves, S.F., Sampaio, B.L., Conceição, E.C., Bara, M.T.F., Paula, J.R. 2013. Environmental factors affecting the concentration of phenolic compounds in Myrcia tomentosa leaves. Brazilian Journal of Pharmacognosy, 23: 230-238.

Campos, M.G., Markham, K.R. 2007. Structure Information from HPLC and on-line Measured Absortion Spectra-flavone, Flavonols and Phenolic Acids. 118 pp., Coimbra University Press, Portugal.

Emerenciano, V.P., Militão, J.S.L.T., Campos, C.C., Romoff, P., Kaplan, M.A.C., Zambon, M., Brant, A.J.C. 2001. Flavonoids as chemotaxonomic markers for Asteraceae. Biochemical Systematrics and Ecology, 29: 947-957.

Falleh, H., Ksouri, R., Medini, F., Guyot, S., Abdelly, C., Magné, C. 2011. Antioxidant activity and phenolic composition of the medicinal and edible halophyte Mesembryanthemum edule L. Industrial Crops and Products, 34: 1066-1071.

Fiasson, J., Gluchoff-Fiasson, L.K., Dahlgren, G. 1997. Flavonoid patterns in European Ranunculus L. subgenus Batrachium (Ranunculaceae). Biochemical Systematics and Ecology, 25: 327-333.

Gobbo-Neto, L., Lopes, N.P. 2007. Plantas medicinais: fatores de influência no conteúdo de metabólitos secundários. Quim Nova, 30: 374-381.

González-Rodríguez, A., Arias, D.M., Valencia, S., Oyama, K. 2004. Morphological and RAPD analysis of hybridization between Quercus affinis and Quercus laurina (Fagaceae), two Mexican red oaks. American Journal of Botany, 91: 401-409.

Gurpreet, K., Mohammad, A., Sarwar, A.M. 2008. Quercus infectoria galls possess antioxidant activity and abrogates oxidative stress-induced functional alterations in murine macrophages. Chemico-Bio- logical Interactions, 171: 272-282.

Hadacek, F. 2002. Secondary metabolites as plant traits: current assessment and future perspectives. Critical Reviews in Plant Science, 21: 273-322.

Hammer, O., Harper, D.A.T., Ryan, P.D. 2001. PAST: Paleontological statistics software for education and data analysis. Paleontologia Electronica, 4: 1-9.

Harborne, J.B., Williams, C.A. 2000. Advance in flavonoid research since 1992. Phytochemistry, 55: 481504.

Iftikhar, B., Perveen, S., Malik, S., Sultana, N., Arayne, S., Muhammad, P. 2009. Structural determination of quercusides A and B, new flavonoid flucosides from Quercus incana, by 1D and 2D NMR. Spectroscopy Magnetic Resonance in Chemistry, 47: 605608.

Ishimaru, K., Ishimatsu, M., Nonaka, G-I., Mihashi, K., Iwase, Y., Nishioka, I. 1988. Tannins and related compounds. LXXI. Isolation and characterization of mongolicins A and B, novel flavono-ellagitannins from Quercus mongolica var. grosseserrata. Chemical \& Pharmaceutical Bulletin, 36: 3312-3318.

Ishimaru, K., Nonaka, G.I., Nishioka, I. 1987. Flavan3-ol and procyanidin glycosides from Quercus miyagii. Phytochemistry, 26: 1167-1170.

Jung-Il, K., Ho-Hyun, K., Sungun, K., Kyoung-Tae, L., In-Hye, H., Wan-Kyunn, W. 2008. Antioxidative compounds from Quercus salicina blume stem. Archives of Pharmacal Research, 31: 274-278.

Karageorgou, P., Manetas, Y. 2006. The importance of being red when young: anthocyanins and the protection of young leaves of Quercus coccifera from insect herbivory and excess light. Tree Physiology, 26: 613-621.

Karioti, A., Tooulakou, G., Bilia, A.R., Psaras, G.K., Karabourniotis, G., Skaltsa, H. 2011. Erinea formation on Quercus ilex leaves: Anatomical, physiological and chemical responses of leaf trichomes against mite attack. Phytochemistry, 72: 230-237.

Kruskal, W.H., Wallis, A.W. 1952. Use of ranks in onecriterion variance analysis. Journal of American Statistical Association, 47: 583-621

Lozoya-Saldaña, H., Rivera-Hinojosa, R., Colinas-León, M.T. 2007. Fenoles, peroxidasas y fenilalanina amonio-liasa: su relación con la resistencia genética de clones de papa (Solanun tuberosum L.) contra el tizón tardío (Phytophthora infestans Mont. De Bary). Agrociencia, 41: 479-489.

Mabry, T.J., Markham, K.M., Thomas, M.B. 1970. The 
Systematic Identification of Flavonoids. 354 pp. Springer-Verlag, New York, USA.

Marinova, D., Ribarova, F., Atanassova, D. 2005. Total phenolics and total flavonoids in Bulgarian fruits and vegetables. Journal of the University of Chemical Technology and Metallurgy, 40: 255-260.

Meyer, S., Louis, J., Moise, N., Piolot, T., Baudin, X., Cerovic, Z.G. 2009. Developmental changes in spatial distribution of in vivo fluorescence and epidermal UV absorbance over Quercus petraea leaves. Annals of Botany, 104: 621-633.

Míka, V., Kubáò, V., Klejdus, B., Odstrèilová, V., Nerušil, P. 2005. Phenolic compounds as chemical markers of low taxonomic levels in the family Poaceae. Plant Soil Environment, 51: 506-512.

Miller, D.P., Howell, G.S., Michaelis, C.S., Dickmann, D.I. 1992. The content of phenolic acid and aldehide flavor components of white oak as affected by site and species. American Journal of Enology and Viticulture, 43: 333-338.

Monteiro, J.M., Albuquerque, U.P., Lins Neto E.M.F., Araújo, E.L, Albuquerque, M.M, Amorim E.L.C. 2006. The effects of seasonal climate changes in the Caatinga on tannin level. Brazilian Journal of Pharmacognosy, 16: 338-344.

Rivas-Arreola, M.J., Rocha-Guzmán, N.E., GallegosInfante, J.A., González-Laredo, R.F., RosalesCastro, M., Bacon, J.R., Rong (Tsao) Cao, Proulx, A., Intriago-Ortega, P. 2010. Antioxidant activity of oak (Quercus) leaves infusions against free radicals and their cardioprotective potential. Pakistan Journal of Biological Sciences, 13: 537545.

Rodríguez, I., Romero, S. 2007. Arquitectura foliar de diez especies de encino (Quercus, Fagaceae) de México. Acta Botánica Mexicana, 81: 9-34.

Romussi, G., Parodi, B., Caviglioli, G. 1991. Flavonoid glycosides from Quercus pubescens Willd., Quercus cerris L. and Quercus ilex L. 14. Contents of Cupuliferae. Pharmazie, 46: 679.

Romussi, G., Bignardi, G., Pizza, C. 1988. Constituents of cupuliferae, XII. Minor acylated flavonoids from
Quercus cerris L. European Journal of Organic Chemistry, 10: 989-991.

Rzedowski, J. 2006. Vegetación de México. 504 pp. $1^{a}$ Edición Digital. Comisión Nacional para el conocimiento y Uso de la biodiversidad. México.

Salminen, J.P., Roslin, T., Karonen, M., Sinkkonen, J., Pihlaja, K., Pulkkinen, P. 2004. Seasonal variation in the content of hidrolizable tannins, flavonoid glycosides, and proanthocyanidins in oak leaves. Journal of Chemical Ecology, 30: 1693-1711.

Santos, S.C., Costa W.F., Batista, F., Santos, L.R., Ferri P.H, Ferreira, H.D, Seraphin J.C. 2006. Seasonal variation tannins in barks of barbatimao. Brazilian Journal of Pharmacognosy, 16: 552-556.

Valencia, A.S. 2004. Diversidad del género Quercus (Fagaceae) en México. Boletín de la Sociedad Botánica de México, 75: 33-53.

Van Alstyne, K.L., McCarthy III, J.J., Hustead C.L., Kearns L.J. 1999. Pholorotannin allocation among tissues of Northeastern Pacific kelps and rockweeds. Journal of Phycology, 35: 483-492.

Veit, M., Beckert, C., Höhne, C., Bauer, K., Geiger, H. 1995. Interspecific and intraspecific variation of phenolics in the genus Equisetum subgenus Equisetum. Phytochemistry, 38: 881-891.

Wang, L.L., Jiang, M.X., Xu, S.X., Sun, Q.S., Zeng, G.Y., Zhou, Y.J. 2010.Two acylated flavonoid glycosides from the leaves of Quercus dentata. Natural Product Communications, 5: 1597-1599.

Warren, J.M., Bassman, J.H., Mattinson, D.S., Fellman, J.K., Edwards, G.E., Robberecht, R. 2002. Alteration of foliar flavonoid chemistry induced by enhanced UV-B radiation in field ground Pinus ponderosa, Quercus rubra and Pseudotsuga menziessi. Journal of Photochemistry and Photobiology B: Biology, 66: 125-133.

Yeon, S.L., Jin Kyu, K., Young Soo, B., Moo-Ho, W., Il-Jun, K., Soon Sung, L. 2011. Inhibitory effect of glucodistylin from the bark of Quercus acutissima on human recombinant aldose reductase and sorbitol accumulation. Archives of Pharmacal Research, 34: 211-215. 